\title{
Strategies for High End High Rise Residential Property Using Marketing Mix during a Soft Market in Kuala Lumpur
}

\author{
Anuar Alias, Zafirah Al Sadat Zyed, Chong Sze Ning \\ Department of Estate Management, Faculty of Built Environment, University of Malaya \\ *Corresponding author: zafirahzyed@um.edu.my
}

\begin{abstract}
Developers face challenges and issues to sell properties when soft market happens. Thus, effective strategies must be identified to reach out to potential buyers. According to the information obtained from National Property Information Centre (NAPIC), the percentage of overhang and unsold high end high rise residential properties in Kuala Lumpur experienced drastic increase in recent years. The aim of this study is to identify developer's strategies within the marketing mix for high end high rise residential property in soft property market. This study is designed to investigate feedback of house buyers in Kuala Lumpur towards developer's strategies implemented in soft property market. Questionnaire survey was adopted in this study. The questionnaire is designed in accordance to buyers' perspective on developer's strategies based on the "Marketing Mix" which consists of price, product, place and promotion. The respondents' feedback is important for the analysis of developer's strategies. The findings show that when soft market happens, the features of the product are the most important factor in house purchase. Therefore, the elements under product should be focused to complement other segments of marketing mix especially price strategy.
\end{abstract}

Keywords: soft market, high end high rise residential properties, effective strategies, marketing mix

\subsection{INTRODUCTION}

The Chartered Institute of Marketing (CIM), UK (2016) defined marketing as "the management process responsible for identifying, anticipating and satisfying customer requirements profitably". Scott (2016) stated that marketing requires understanding towards your buyers and solve their problems by creating valuable products, services, and information for them. Developers are aware of the importance of marketing and its influence of mass exposure to the public. Proper market study must be done to create effective marketing strategies. The function of marketing strategies is to concentrate on target customers to maximize profit in shortest time span.

Effective strategies certainly play a vital role in attracting purchasers especially in soft market where the market has more sellers than buyers. The house buyers hold negotiation power in property transaction. Thus, the attractiveness of marketing strategies will indirectly affect the developers to uphold soft high end residential property market. The aim of this study is to identify developer's strategies within the marketing mix for high end high rise residential property in soft property market. Residential property has always been preferred investment in real estate. The residential property performance is getting sluggish but the market demand for residential property is going strong. Therefore, the developers should compete smartly to survive in the buyer's market. This research will contribute to the study of developer's strategies in soft market to improve poor residential sales performance. 


\subsection{LITERATURE REVIEW}

High end high rise residential property refers to condominiums which are more than 10 floors located in prime area of the city. Condominiums are built in with facilities, amenities and safety features (Seo and Omar, 2010). According to CAGAMAS (2013), high end residential property is range at RM500,000 to 1 million. Reduction of price occurs due to excessive supply when the demand is limited. Marketing strategies are the effective marketing activities to obtain desire outcome from the target market. Thus, marketing mix comprising of price, place, promotion and product is very important in a sale driven real estate environment.

\subsection{Property Market in General}

The performance of economy will affect the property market. The real estate market fluctuates up and down according to the theory of "multi-layered real estate cake" (Lundquist, 2007) The analogy stated that the value of real estate is impacted by the factors of macro-economy and micro-economy by creating ripple effect throughout the real estate market.

According to Ishak (2013), there are three phases in the formation of property bubble:

Phase 1 - Property value increase rapidly. (During year 2010 to year 2014)

Phase 2 - Property value is beyond affordable at above 3 times of median annual income. Malaysia is about 5.5 times of median annual income which indicates "severely unaffordable".

Phase 3 - Property value declines and bubble burst.

\subsection{Residential Market Performance in Kuala Lumpur}

According to Overview of the Property Market Report First Half 2016 for Kuala Lumpur by NAPIC (2016), the sign of soft residential market is distinctive with poor transaction performance these few years. For instance, Figure 1 illustrates the residential sales performance in Kuala Lumpur is weakening by $-14.5 \%$ of poor transacted sales. As for Figure 2, it shows that overhang and unsold properties increase throughout the years and achieve the peak at 2016. Therefore, developers have been using marketing strategies to sell off overhang and unsold properties.

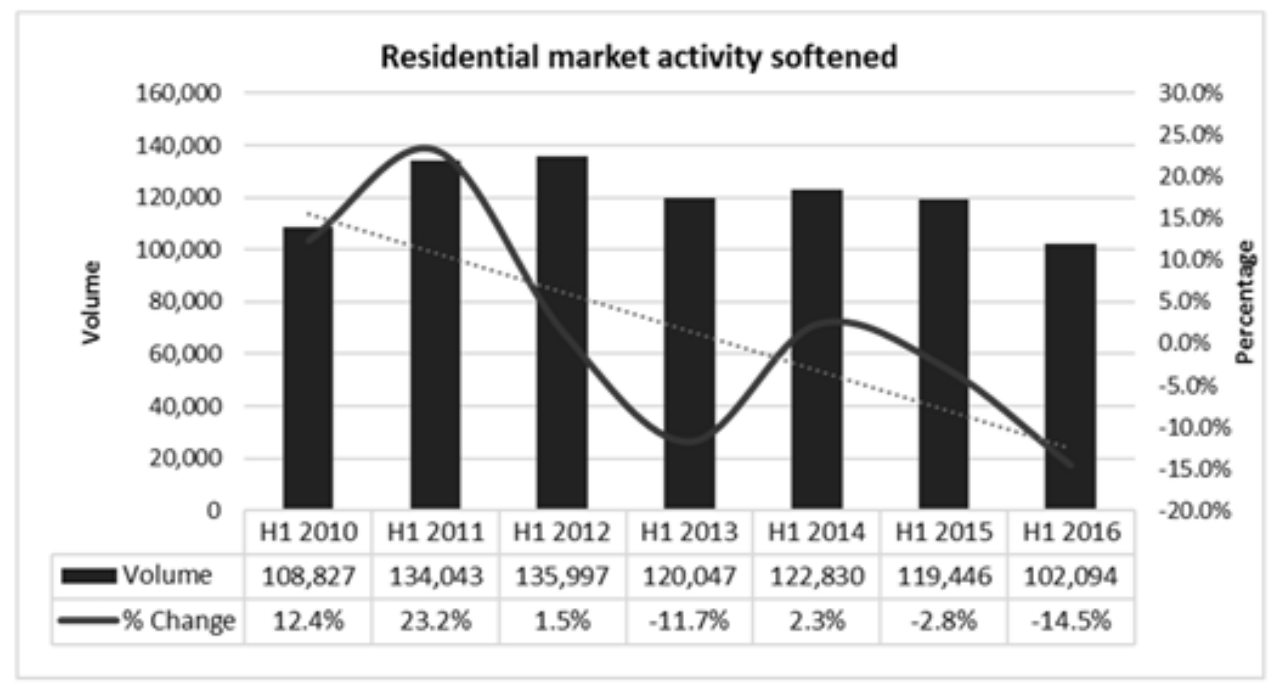

Figure 1: Residential market performance in Kuala Lumpur Source: NAPIC, 2016 


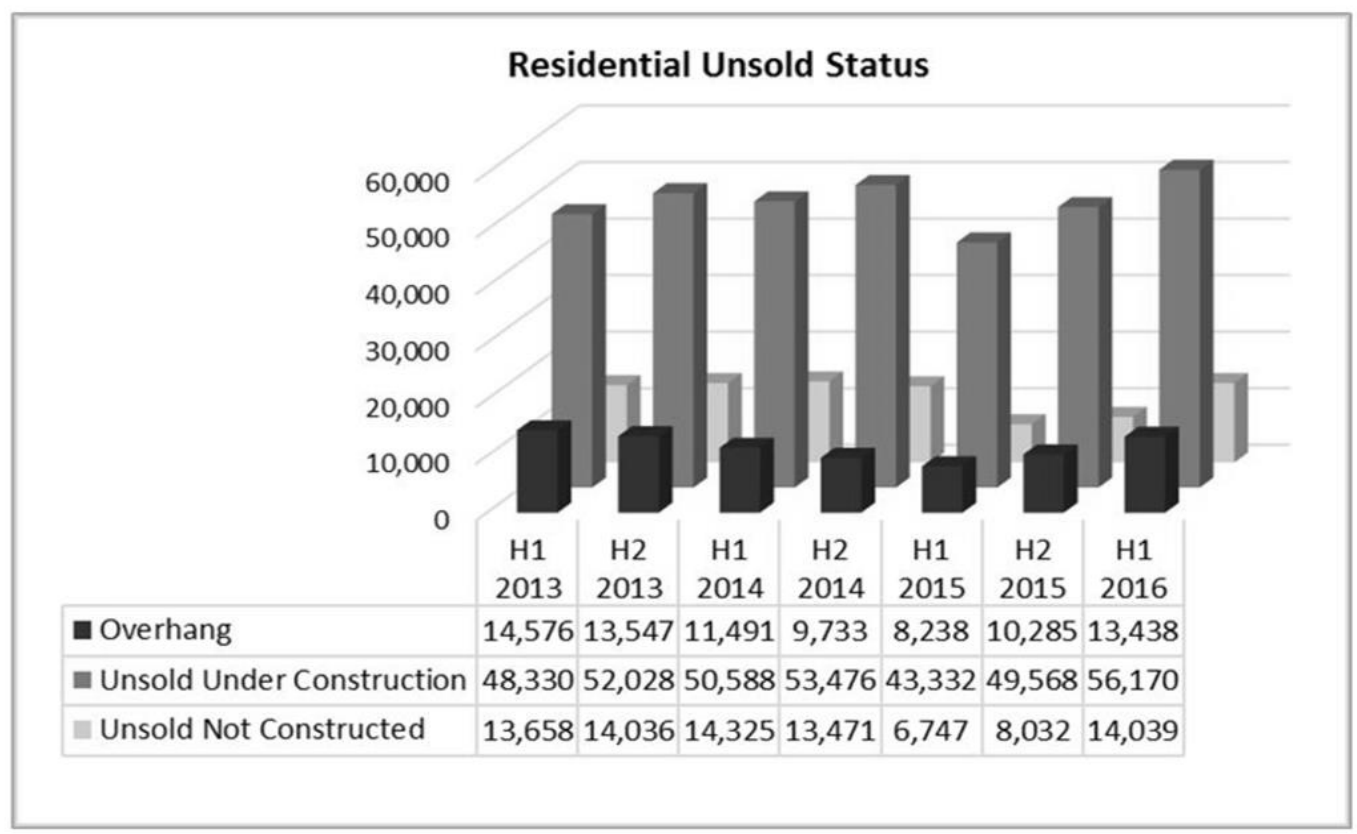

Figure 2: Residential unsold status in Kuala Lumpur Source: NAPIC, 2016

Table 1 shows the performance of high rise residential properties performance in Kuala Lumpur. The overall performance is relatively bad, indicated by the declining trend in terms of transaction activity, price and occupancy rate.

Table 1: Performance of high rise residential properties in Kuala Lumpur

\begin{tabular}{|c|c|c|c|c|c|c|}
\hline & \multicolumn{2}{|c|}{ Transaction Activity } & \multicolumn{2}{|c|}{ Price Trend } & \multicolumn{2}{|c|}{ Take-up / Occupancy Rate } \\
\hline & 2015 & 2016 & 2015 & 2016 & 2015 & 2016 \\
\hline \multicolumn{7}{|c|}{ MAIN MARKET } \\
\hline Klang Valley & $\boldsymbol{\nabla}$ & $\nabla$ & $\boldsymbol{\nabla}$ & 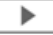 & $\nabla$ & $\nabla$ \\
\hline
\end{tabular}

New constructions are reducing and generate at a slower pace. Productions are decreasing as the current stocks are still holding in the market. This shows that unsold units are increasing and sluggish market is happening. Property prices decreased gradually but most of the properties still maintain at their selling price. (MIER's Residential Property Survey Report 4Q 2015, 2016).

\subsection{Soft Market in Kuala Lumpur}

According to DBS group research on Kuala Lumpur property market, the analysis showed few property trends and performances such as strong demand for affordable landed properties and developers boost sales in poor sentiment using marketing strategies (Quah, 2016).

This study is supported by Knight Frank research in 2015 (Knight Frank Real Estate Highlights (2015) that showed the construction of high end condominiums in Kuala Lumpur will be deferred due to the weak market sentiment and massive incoming supply. The competitions for existing and upcoming supply have caused the selling prices and rental to be stagnant. Therefore, the developers are using innovative products and promotion strategies with creative financial deals such as offering leaseback arrangements, pool management program and guaranteed rental returns in this challenging market to attract house buyers. Figure 3 illustrates the formation of soft market in Kuala Lumpur: 


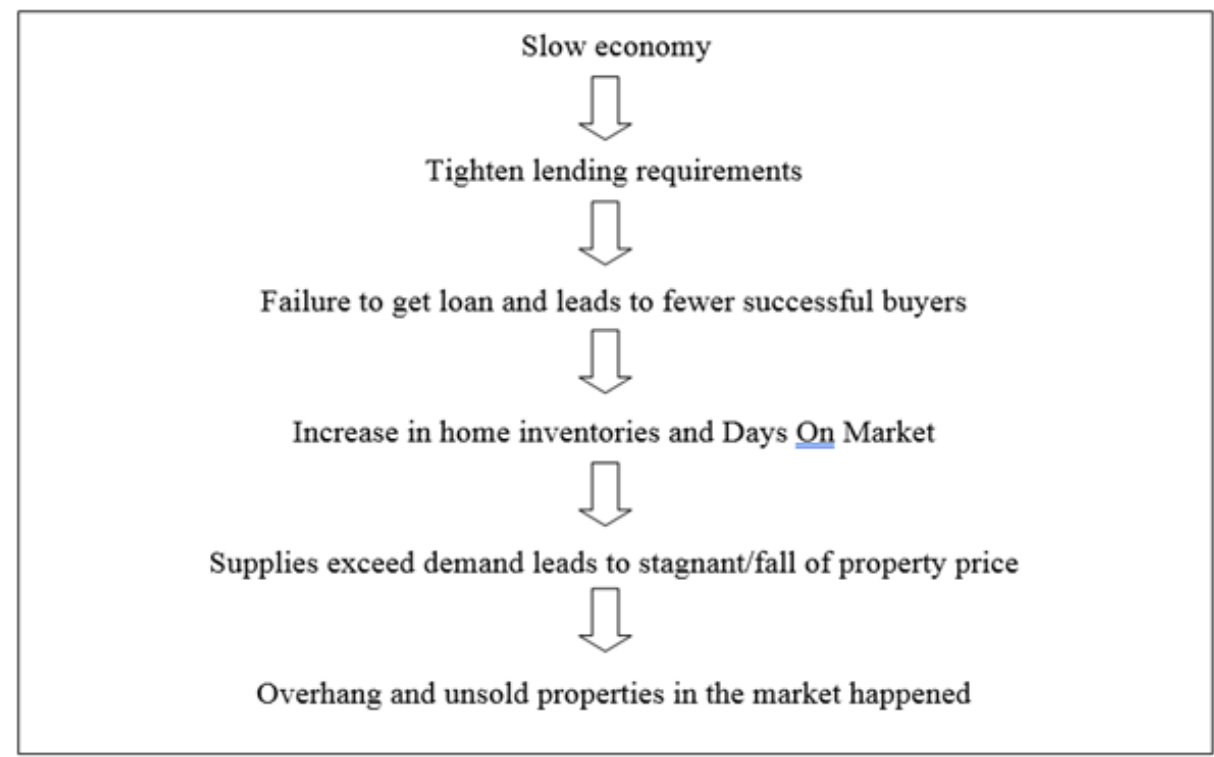

Figure 3: Formation of soft market in Kuala Lumpur

\subsection{Characteristics of Soft Market}

According to Kiplinger (2014), real estate is related to the force of supply and demand. Wide variety of properties for buyers' selection will lead to lower property prices. Soft market happened from the outlook of macroeconomic due to:

\subsubsection{Weak Economy}

Gross Domestic Product (GDP) is the economy health indicator through the analysis of income approach or expenditure approach. GDP is used to indicate the economy performance of previous quarter or year. Therefore, strong economy performance will indicate higher percentage (Investopedia, 2016). The GDP of Malaysia declines starting from July 2014 by 6.5 to 4 in July 2016 which indicates the weak economy (Trading Economics, 2016).

\subsubsection{Loan Approval Failure Increase}

Loan approval is important for house buyers financing. The rejection of loan application and approval increases especially for new units. The capital invested by developers in housing sector stay stagnant due to increment in construction cost. The uncertainties of economic condition in Malaysia have caused the house buyers to be extra caution which lead to weak buying sentiment. The analysis of loans applied and approved for residential purchase is stated in Table 2 (MIER's Residential Property Survey Report 4Q 2015, 2016).

Table 2: Loans Applied and Approved for Residential Properties Purchase by Year

\begin{tabular}{|l|c|c|c|c|}
\hline & $\mathbf{2 0 1 2}$ & $\mathbf{2 0 1 3}$ & $\mathbf{2 0 1 4}$ & $\mathbf{2 0 1 5}$ \\
\hline Loans applied (RM mil) & $193,743.4$ & $245,903.8$ & $223,850.3$ & $206,031.8$ \\
\hline Loans approved (RM mil) & $92,834.0$ & $121,000.6$ & $121,091.5$ & $103,412.1$ \\
\hline Percentage approved & 47.92 & 49.21 & 54.09 & 50.19 \\
\hline
\end{tabular}

Source: Bank Negara Malaysia (BNM), 2016 


\subsubsection{Increase in Mortgage Rate}

Base Lending Rate (BLR) is set by Bank Negara Malaysia (BNM) and determined by Overnight Policy Rate (OPR). OPR is the interest rate charged to a bank which lends from another bank (CIMB, 2016). OPR is set by Bank Negara Malaysia (BNM) and the latest rate is at 3\% from 13 July 2016 (PTLM, 2016). The OPR will create a ripple effect in loan finance. The higher OPR is, the higher the loan interest rate will be and vice versa. Base Rate (BR) introduced by BNM in 2015 is based on the bank's financing cost and Statutory Reserve Requirement (SRR) and is determined by respective banks in which BNM will not interfere (Ho, 2016). The general base lending rate/base rate record in Malaysia showed the increment of 5.55\% in 2010 to $6.95 \%$ in 2016 (www.blr.my).

\subsubsection{Stagnant Wages}

The median monthly salaries and wages received in 2015 for male and female households are RM1,600 whereas for the mean received is RM2,312. The male and female received RM2,345 and RM2,254 respectively. The median monthly salaries \& wages received in 2015 increased by 6.5 per cent which accumulated to RM1,600 as compared to RM1,500 in 2014. Meanwhile, the mean monthly salaries \& wages increased to RM2,312 compared to RM2,193 in the previous year with an annual growth rate of 5.3 per cent. Although there is small margin of salary increment, the wages have been stagnant for years taking into the consideration of inflation (Department of Statistics, Malaysia, 2016).

Loan repayment and housing affordability is restricted to lower and middle income group due to current financial terms such as high interest rates and short loan periods. Therefore, joint ownership is necessary in Kuala Lumpur for home ownership. Middle income group are neglected in ownership of affordable housing since higher income group have the ability for loan repayment while lower income group are supported by government housing schemes such as My First Home Scheme.

\subsubsection{Increase in Unemployment Rate}

Unemployed is defined as the person has the intention to work but does not have job available. The statistics increased by 38,600 or 8.3\% year-on-year (YOY), from 463,200 in June 2015 to 501,800 in June 2016 (Krinstitute, 2016).

\subsubsection{Property Supply Increase}

Property supply in the market consists of overhang property, unsold properties under construction and unsold properties not constructed. Data was obtained from NAPIC for high rise residential in Malaysia and narrow down into Kuala Lumpur (NAPIC, 2016).

\section{Overhang Property}

According to NAPIC, overhang is defined as properties that are completed and issued with Certificates of Fitness for Occupation (CFO) or Temporary Certificates of Fitness for Occupation (TCFO) but remain unsold despite having been put on the market for at least nine months.

a) Overhang Property in Malaysia

The major properties overhang occurred in states such as Kuala Lumpur, Selangor, Johor, Penang, Perak and Malacca. From year 2014 to year 2016, the data showed an upward trend. However, in Q3 2015, the total number of overhang property slightly declined. It increased by 1,160 or 9.5\% quarter-on-quarter (QOQ), from 12,268 in Q1 2016 to 13,428 in Q2 2016. As for Kuala Lumpur, the total number increased from Q4 2014 to Q2 2015 and depreciated until Q1 2016. It showed an increase by 214 or 34.4\% quarter-on-quarter (QOQ) from Q1 2016 to Q2 2016. 
b) Overhang Property in Kuala Lumpur

The overhang property in Kuala Lumpur mainly comprised of high rise residential. The overall percentage of Q4 2014 to Q2 2015 is at the range of 60\% to 70\%. For Q3 2015 to Q4 2015, the percentage has decreased to $31.77 \%$ and $26.42 \%$ respectively. The total percentage drastically shot up to $91.8 \%$ and the overhang high rise residential increased 398 units in Q1 2016. The overhang high rise properties in Q1 2016 from 571 units increased to 735 units with approximately $90 \%$ of the total percentage indicating the risks of soft market.

\section{Unsold Properties under Construction in Malaysia}

NAPIC stated that unsold properties under construction are those developments with building plan approvals and under construction remain unsold after launched for more than nine months.

a) Unsold Properties under Construction in Malaysia

The major unsold properties under construction happened in the states of Kuala Lumpur, Selangor, Johor, Penang, and Perak. The trend is stable with the massive total numbers stated at the range of 50,000 units to 70,000 units. The total number from Q4 2014 to Q2 2016 fluctuates. Q4 2015 has the highest total number which is 68,780 units. It increased by 5,330 or $10.5 \%$ quarter-on-quarter (QOQ), from 50,840 in Q1 2016 to 56,170 in Q2 2016. As for Kuala Lumpur, the trend is unstable. Q2 2015 achieved the highest number of 10,742 units and it dramatically dropped to the lowest number of 3,658 units at Q3 2015. It showed an increase by 328 or 8.3\% quarter-on-quarter (QOQ) from Q1 2016 to Q2 2016.

b) Unsold Properties under Construction in Kuala Lumpur

The unsold properties under construction in Kuala Lumpur mainly consist of high rise residential. The overall percentage is rather low from Q4 2014 to Q4 2015. Q4 2015 which is the lowest point has drastically increased to Q1 2016 at 64.8\%. Year 2016 is the peak at 3,887 units (97.81\%) at Q1 and 4,253 units (98.96\%) at Q2. The sudden shot up signifies the signs of soft market.

\section{Unsold Properties Not Constructed}

According to NAPIC, unsold properties not constructed are those with building plan approvals but are not yet constructed remain unsold after launched for more than nine months.

a) Unsold Properties Not Constructed in Malaysia

The major unsold properties not constructed in Malaysia are Kuala Lumpur, Selangor, Johor and Kedah. The trend fluctuates and the peak is at Q2 2016 which is 14,039 units whereas the lowest point is at Q1 2016 which is 8,815. Year 2016 experienced the drastic increase of 5,224 units or 59.3\% quarter-on-quarter (QOQ) basis. As for Kuala Lumpur in general, the data showed steady increase but Q1 2016 to Q2 2016 increased by 3039 units or $98.1 \%$.

b) Unsold Properties Not Constructed in Kuala Lumpur

The majority unsold properties not constructed in Kuala Lumpur consist of high rise residential. The overall percentage and numbers increase steadily. However, for year 2016, Q1 and Q2 both achieved $100 \%$ with 3,097 units and 6,136 units unsold not constructed.

\subsubsection{Signs of Soft Market in Microeconomic}

Lundquist (2007) proposed that the declining of real estate market or beginning of slow market is the indication of soft market. The signs of soft market from view of microeconomic are: 
- Less offers

- Less traffic for listings

- More credit offered to buyers

- More price reductions

- Listings priced lower than sales

- Increase of housing inventory

- Days on market increasing

\subsubsection{Sign of Seller's Behaviour in Soft Market}

Denomme (2009) specified the seller's behaviors during a soft market to be as follows:

- Offer buyer incentives

- Setting slightly lower price to competitors

- Employ real estate agent

- Always prepared for viewing

- Improve property first impression

\subsection{The Marketing Mix 4Ps}

The marketing mix is a tool which uses to justify the buyers' needs for marketing strategies decision making. Iman (2002) stated that marketing mix 4Ps (price, product, promotion and place) is the most common framework in the marketing model. He explained developers used marketing mix 4Ps to achieve their business objectives as shown in Table 4:

Table 4: Explanation of Real Estate Marketing Mix 4Ps in Malaysia Context

\begin{tabular}{|c|l|}
\hline 4Ps & \multicolumn{1}{c|}{ Application in real estate } \\
\hline Products & $\begin{array}{l}\text { Real estate products offered by the developers to the buyers in tangible and intangible } \\
\text { elements might influence the buyers' decision. }\end{array}$ \\
\hline Price & $\begin{array}{l}\text { This element indicates the total amount of money buyers needed to purchase a property. } \\
\text { This is the first consideration of buyer's decision according to the factors of initial } \\
\text { evaluation stage. }\end{array}$ \\
\hline Place & Location and concept of the property which provide marketing information to the buyers. \\
\hline Promotion & $\begin{array}{l}\text { Activities that channel down the unique selling point of the property to the potential } \\
\text { buyers. }\end{array}$ \\
\hline
\end{tabular}

Source: Iman (2002)

\subsection{Current Developer's Strategies}

The developers are eager to boost sales in slow market through the introduction of creative strategies. These initiatives are designed for unsold, overhang and upcoming supply units. There are no law regulations against the developers' strategies. The motive of developers behind of these incentives is a strong indication to accommodate the urgency to sell. Therefore, all parties especially buyers are advised to be caution with the attractive promotions (Thean, 2016). The information in Table 5 shows current strategies used by developers within the 4Ps that were collected from property exhibition and internet sources.

Table 5: Current developer's strategies in a soft market

\begin{tabular}{|c|c|}
\hline PRODUCT & PROMOTION \\
\hline $\begin{array}{l}\text { - } \quad \text { Good branding } \\
\text { - } \quad \text { Unique Selling Point such as: } \\
\text { Concept } \\
\text { Lifestyle Residences (Verve Suites, Mont } \\
\text { Kiara) }\end{array}$ & $\begin{array}{ll}\text { - } & \text { Advertising (Social Media) } \\
\text { - } & \text { Conventional Media } \\
\text { - } & \text { Digital Platform } \\
\text { - } & \text { Public Relations } \\
\text { - } & \text { Direct Marketing }\end{array}$ \\
\hline
\end{tabular}




\begin{tabular}{|c|c|}
\hline $\begin{array}{c}\text { Integrated development (Sunway Velocity) } \\
\text { App-Linked Development (Novum Bangsar } \\
\text { South) } \\
\text { Luxury (Four Seasons Place Kuala Lumpur) } \\
>\quad \text { Theme } \\
\text { Green (Inwood Residences, Pantai Sentul } \\
\text { Park) } \\
\text { Modern (The Fennel, Sentul) } \\
\text { Lakeside (Lakeville, Jalan Kuching) } \\
\text { Nature (Lakepark Residence) } \\
>\quad \text { Branding and reputation } \\
\text { Signature names of developer (Eco Sky) } \\
>\quad \text { Architect } \\
\text { Foreign (The Fennel, Sentul) } \\
\text { Art-Piece Building (Arte Series) } \\
>\quad \text { Infrastructure } \\
\text { Transit - Oriented Development (EkoCheras } \\
\& \text { Sunway Velocity) }\end{array}$ & $\begin{array}{l}\text { - } \text { Free Stay Campaign } \\
\text { - } \quad \text { Carnival, Celebration \& Concert Tour } \\
\text { - Lucky draw \& Sponsorship as reward or } \\
\text { award } \\
\text { - } \quad \text { Free Legal Fees } \\
\text { - } \quad \text { Free furniture } \\
\text { - } \text { Early bird rebates }\end{array}$ \\
\hline PRICE & PLACE \\
\hline $\begin{array}{ll}\text { - } & \text { Reside-and-purchase scheme } \\
\text { - } & \text { 'Safety net' loans } \\
\text { - } & \text { 10:90 scheme } \\
\text { - } & \text { Buy now pay later } \\
\text { - } & \text { Guarantee Rental Return (GRR) }\end{array}$ & $\begin{array}{ll}\text { - } & \text { Property exhibition } \\
\text { - } & \text { Launch events such as exclusive preview and } \\
\text { official launch } \\
\text { - } \quad \text { Purpose Built Sales Gallery } \\
\text { - } \quad \text { Show Units }\end{array}$ \\
\hline
\end{tabular}

Source: Author, 2016

\subsection{METHODOLOGY}

This study is designed to investigate feedback of house buyers in Kuala Lumpur towards developer's strategies implemented in soft property market. Questionnaire survey was adopted in this study. The questionnaire is designed in accordance to buyers' perspective on developer's strategies based on the "Marketing Mix 4Ps" which consists of price, product, place and promotion. The questionnaire consists of 51 questions in two sections. 12 questions are provided in Section A. This section is necessary to obtain the respondent's profile. As for section B which comprised of 39 questions are derived from the dependent and independent variables of the theoretical framework. In section B, the questions are derived from the developer's strategies within the Marketing Mix. This section is important as the outcome of the study is based on the analysis of buyer's perspective towards these strategies. The elements of "Marketing Mix 4Ps" which are the price, promotion, place and product were arranged in Likert-Scale format of the following scale: $1=$ strongly disagree, $2=$ disagree, $3=$ neutral, $4=$ agree and $5=$ strongly agree. Summary of questionnaire is listed in Table 6 :

Table 6 Summary of Questionnaire Design

\begin{tabular}{|l|l|l|}
\hline \multicolumn{2}{|l|}{ VARIABLE } & NO OF ELEMENTS \\
\hline Section A: Profile & 1 & Section A, No. 1 \\
\hline Gender & 1 & Section A, No. 2 \\
\hline Age & 1 & Section A, No. 3 \\
\hline Occupation & 1 & Section A, No. 4 \\
\hline Marital Status & 1 & Section A, No. 5 \\
\hline Household Members & 1 & Section A, No. 6 \\
\hline Type of property selection & 1 & Section A, No. 7 \\
\hline Monthly household income & 1 & Section A, No. 8 \\
\hline Purpose of house purchase & 1 & Section A, No. 9 \\
\hline Houses owned & 1 & Section A, No. 10 \\
\hline Next house in planning & 1 & Section A, No. 11 \\
\hline Preference to purchase &
\end{tabular}




\begin{tabular}{|l|l|l|}
\hline Preferred house range price & 1 & Section A, No. 12 \\
\hline Section B: Developer's strategies & \multicolumn{2}{|c|}{} \\
\hline Product & 6 & Section B, No. 1-6 \\
\hline Price & 10 & Section B, No. 10-19 \\
\hline Promotion & 9 & Section B, No. 20-28 \\
\hline Place & 7 & Section B, No. 29-35 \\
\hline Soft Market & 6 & Section B, No. 7-9,36-38 \\
\hline Ranking & 1 & Section B, No. 39 \\
\hline
\end{tabular}

The questionnaires which were distributed in the Kuala Lumpur via email to those who work or live in Kuala Lumpur. The targeted feedbacks were 150 sets, 139 sets were collected back and only 120 sets were valid. Missing data and answers were detected in the remaining 19 questionnaires. The response rate is $92.67 \%$. Cross tabulation analysis, relative important index and descriptive statistics are conducted in this research in which data analysis was conducted using Statistical Package for Social Science (SPSS). The developer's strategies were analysed based on buyer's perspective.

\subsection{RESULTS AND DISCUSSION}

The developers are finding difficulties to dispose the available and upcoming properties during the soft property market in Kuala Lumpur. Thus, the strategies within the current marketing mix 4Ps created by the developers is being studied from buyer's perspective in this study to provide recommendations to improve residential market sales performance. Table 7 and Table 8 illustrate the overall mean score ranking and relative important index ranking respectively. These rankings are derived from analysis of the questionnaire according to buyer's perspective. Based on the ranking shown in both tables, product is the most important factor in developers' marketing mix 4Ps from the buyer's perspective. Product is positioned at the highest ranking in overall mean score from descriptive statistics and relative important index.

From the responses shown in table 7 and table 8 , house buyer's purchase consideration has shifted from price to product in a soft market. Therefore, the results of the analysis highlighted the importance of product. The developers tend to focus on the concept and theme of the project as unique selling point of the development to mark up the selling price. However, the buyers would face difficulties to receive loans in soft market which leads to the inability to purchase by the house buyers. Thus, the realignment of developer's product and buyer's expectation needs to be made. Since product is the most important factor in a soft market, the developers shall ensure that there shall be proper product strategies in current market situation.

The house buyers' lack of awareness about the pricing strategies promoted by the developers is reflected in the overall mean score of 2.84 showing the lack of understanding of respondents towards developer's strategies. Reside and Purchase Scheme is ranked first and "Safety Net" Loan is ranked at last, which is the fifth place.

As for promotion and place strategies, the components under these strategies are commonly applied in the industry. Both strategies are irrelevant in purchasing considerations but they trigger the buyer's intention to purchase.

Table 7: Overall mean score ranking

\begin{tabular}{|c|c|c|}
\hline Ranking & Marketing Mix 4Ps & Overall Mean Score \\
\hline $\mathbf{1}$ & Product & 4.02 \\
\hline $\mathbf{2}$ & Price & 3.71 \\
\hline $\mathbf{3}$ & Promotion & 3.45 \\
\hline $\mathbf{4}$ & Place & 3.20 \\
\hline
\end{tabular}

Table 8: Relative Important Index ranking 


\begin{tabular}{|c|c|c|}
\hline Ranking & Marketing Mix 4Ps & Relative Important Index \\
\hline $\mathbf{1}$ & Product & 0.787 \\
\hline $\mathbf{2}$ & Price & 0.737 \\
\hline $\mathbf{3}$ & Promotion & 0.690 \\
\hline $\mathbf{4}$ & Place & 0.640 \\
\hline
\end{tabular}

\subsection{CONCLUSION}

Price will always be the most important concern in property purchase. However, when soft market happens, the features of the product have become the most important factor in house purchase. Therefore, the elements under product should be the center focus to complement other segments of marketing mix 4Ps especially price strategies. However, price strategies will only be effective if the incentives and schemes are beneficial to house buyers. Apart from that, promotion is perceived to be supplementary to price marketing strategy. If the promotion benefits the buyers especially in monetary value, it will become an attraction to the buyers. Developers may consider reducing social media promotion and channel the budget in monetary form.

Lastly, the developers can reduce cost in place strategy by being customer centric for the targeted market. This study justified the need and demand of house buyers by using marketing mix 4Ps. Hence, the developers should improvise their strategies within the marketing mix to improve residential sales performance in the soft market.

\subsection{REFERENCES}

1. Malaysia Base Lending Rate (2016). Retrieved August 20,2016 from http://www.blr.my/

2. The Chartered Institute of Marketing (CIM) (2016). Retrieved April 19,2016, from http://www.cim.co.uk/more/getin2marketing/what-is-marketing/

3. BNM. (2016). Base Rate, Base Lending/Financing Rates and Indicative Effective Lending Rates (1st ed). Retrieved May 5, 2016 from Bank Negara Malaysia Web site: http://www.bnm.gov.my/documents/2016/base_rates/BR\%20\&\%20ELR_160818.pdf

4. CAGAMAS. (2013). Housing The Nation - Policies, Issues and Prospects. Kuala Lumpur: Cagamas Holdings.

5. CIMB. (2016). All You Need to Know About Overnight Policy Rate (Opr), Base Lending Rate (Blr) And Base Financing Rate (BFR) (1st ed.). Retrieved May 10, 2016 from CIMB Web site: http://www.cimbbank.com.my/content/dam/cimb-consumer/personal/ImportantNotices/OPR_BLR_BFR_Info.pdf

6. Denomme, S. (2009). Real Estate Word -- The Hard Reality of a Soft Market. Retrieved May 29, 2016, from Realestateword.com web http://www.realestateword.com/newsletter/archive.php?sid=1\&nid=147\&aid=297

7. Department of Statistics, Malaysia. (2016). Salaries \& Wages Survey Report, Malaysia, 2015. Retrieved April 18, 2016, from https://www.statistics.gov.my/index.php?r=column/pdfPrev\&id=czRyNkJIbDFyYXJFbU5YT VJ1V1BHZz09 
8. Ho, F. (2016). Base Rate vs BLR in Malaysia: How Does BR Work? | iMoney. iMoney Malaysia. Retrieved May 7, 2016, from https://www.imoney.my/articles/all-about-that-basehow-does-base-rate-work

9. Iman, A. (2002). An introduction to property marketing (1st ed.). Johor: Penerbit Universiti Teknologi Malaysia (UTM).

10. Investopedia. (2016). Gross Domestic Product - GDP. Investopedia. Retrieved May 12,2016, from http://www.investopedia.com/terms/g/gdp.asp?ad=dirN\&qo=investopediaSiteSearch\&qsrc=0 $\underline{\& 0=40186}$

11. Ishak, A. (2013). Strategic Property Investor (1st ed.). Ibac Services.

12. Kiplinger, J. (2014). Playing a Soft Housing Market. Retrieved May 21,2016, from www.kiplinger.com Web site: http://www.kiplinger.com/article/investing/T052-C016-S002playing-a-soft-housing-market.html\#

13. Knight Frank Research. (2015). Real Estate Highlights 2nd Half 2015. Kuala Lumpur: Knight Franks.

14. Krinstitute. (2016). Unemployment. Retrieved April 16, 2016, from Krinstitute.org Web site: http://www.krinstitute.org/Indicators-@-Unemployment.aspx

15. Lundquist, R. (2007). How do you know when a real estate market is getting soft?. Retrieved August 8, 2016, from Sacramento Appraisal Blog | Real Estate Appraiser Web site: http://sacramentoappraisalblog.com/2014/05/20/how-do-you-know-when-real-estate-isgetting-soft/

16. MIER's Residential Property Survey Report 4Q 2015. (2016). Retrieved May 15, 2016 from http://rehda.com/wp-content/uploads/2016/05/REHDA-Bulletin-03-March-2016.8.pdf

17. National Property Information Center. (2015). Property Overhang Table Q1 2015 (pp. 13-30). Kuala Lumpur: National Property Information Center.

18. National Property Information Center. (2015). Property Overhang Table Q2 2015 (pp. 13-30). Kuala Lumpur: National Property Information Center.

19. National Property Information Center. (2015). Property Overhang Table Q3 2015 (pp. 13-30). Kuala Lumpur: National Property Information Center.

20. National Property Information Center. (2015). Property Overhang Table Q1 2015 (pp. 13-30). Kuala Lumpur: National Property Information Center.

21. National Property Information Center. (2015). Unsold Not Constructed Property Table Q1 2015 (pp. 13-22). Kuala Lumpur: National Property Information Center.

22. National Property Information Center. (2015). Unsold Not Constructed Property Table Q2 2015 (pp. 13-22). Kuala Lumpur: National Property Information Center.

23. National Property Information Center. (2015). Unsold Not Constructed Property Table Q3 2015 (pp. 13-22). Kuala Lumpur: National Property Information Center. 
24. National Property Information Center. (2015). Unsold Not Constructed Property Table Q4 2015 (pp. 13-22). Kuala Lumpur: National Property Information Center.

25. National Property Information Center. (2015). Unsold Under Construction Property Table Q1 2015 (pp. 13-22). Kuala Lumpur: National Property Information Center.

26. National Property Information Center. (2015). Unsold Under Construction Property Table Q2 2015 (pp. 13-22). Kuala Lumpur: National Property Information Center.

27. National Property Information Center. (2015). Unsold Under Construction Property Table Q3 2015 (pp. 13-22). Kuala Lumpur: National Property Information Center.

28. National Property Information Center. (2015). Unsold Under Construction Property Table Q4 2015 (pp. 13-22). Kuala Lumpur: National Property Information Center.

29. National Property Information Center. (2016). Overview of the property market report first half 2016. [online] National Property Information Center. Retrieved December 10, 2016 from http://file:///C:/Users/user/Downloads/1480384539889OverviewH12016\%20(1).pdf

30. National Property Information Center. (2016). Property Overhang Table Q1 2016 (pp. 11-20). Kuala Lumpur: National Property Information Center.

31. National Property Information Center. (2016). Property Overhang Table Q2 2016 (pp. 11-20). Kuala Lumpur: National Property Information Center.

32. National Property Information Center. (2016). Unsold Not Constructed Property Table Q1 2016 (pp. 11-16). Kuala Lumpur: National Property Information Center.

33. National Property Information Center. (2016). Unsold Not Constructed Property Table Q2 2016 (pp. 11-16). Kuala Lumpur: National Property Information Center.

34. National Property Information Center. (2016). Unsold Under Construction Property Table Q1 2016 (pp. 11-16). Kuala Lumpur: National Property Information Center.

35. National Property Information Center. (2016). Unsold Under Construction Property Table Q2 2016 (pp. 11-16). Kuala Lumpur: National Property Information Center.

36. PTLM. (2016). What you need to know about Home Loans. Retrieved June 15, 2016, from Ptlm.com.my Web site: http://www.ptlm.com.my/index.php/component/k2/32-financeloans/what-you-need-to-know-about-home-loans

37. Quah, H. (2016). Industry Focus Malaysia Property. Kuala Lumpur: DBS Vickers Securities.

38. Scott, D. (2016). 72 Marketing Definitions - Heidi Cohen. Retrieved August 18, 2016, from Heidi Cohen Web site: http://heidicohen.com/marketing-definition/

39. Seo, R. and Omar, S. (2010). A Typology of Modern Housing in Malaysia. International Journal of Human Ecology 11, [online] p.118. Available at: http://www.archresearch.org/ data store 1/JK board/4/2013 1/10.atypologyofmodernhousinginmalaysia_44.pdf [Accessed 9 Dec. 2016].

40. Thean, L. (2016). Creative marketing by developers. Retrieved August 29, 2016, from Business News | The Star Online. Thestar.com.my Web site: 
e-issn: $2229-8568$

http://www.thestar.com.my/business/business-news/2016/05/21/creative-marketing-bydevelopers/

41. Trading Economics. (2016). Malaysia GDP Annual Growth Rate 2000-2018. Retrieved August 29, 2016, from https://tradingeconomics.com/malaysia/gdp-growth-annual 